\title{
MỘT SỐ ĐẶC ĐIỂM ĐỊA CHÂT PLIOCEN - ĐỆ TÚ', ĐỊA CHẤT CÔNG TRİNH KHU VỰC MIỀN TRUNG VÀ ĐÔNG NAM THỀM LỤC ĐỊA VIỆT NAM
}

\author{
MAI THANH TÂN ${ }^{1}$, PHẠM VĂN TY̛ ${ }^{1}$, ĐẠNG VĂN BÁT ${ }^{1}$, \\ LÊ DUY BÁCH ${ }^{2}$, NGUYỄN BIẾU ${ }^{2}$, TRẦN NGHI ${ }^{3}$, LÊ VĂN DUNG ${ }^{4}$ \\ E-mail:mttan@fpt.vn \\ ${ }^{I}$ Truoòng Đại học Mỏ - Địa chất \\ ${ }^{2}$ Tổng hội Địa chất Việt Nam \\ ${ }^{3}$ Trưòng Đại hoc Khoa họ Tụ nhiên - ĐHQGHN \\ ${ }^{4}$ Viện Dầu khí - Tập đoàn Dầu khi Quốc gia Việt Nam \\ Ngày nhận bài: 20-4-2011
}

\section{Mở đầu}

Việt Nam có vùng thềm lục địa rộng lớn với đặc điểm địa chất phức tạp. Nghiên cứu trầm tích Pliocen Đệ tứ thềm lục địa Việt Nam rất quan trọng trong việc xác định các đặc điểm địa chất biển nông, đánh giá tiềm năng khoáng sản, đánh giá điều kiện xây dựng công trình biển. Bằng tổ hợp các phương pháp địa chấn (địa chấn $2 \mathrm{D}, 3 \mathrm{D}$ và địa chấn nông phân giải cao), phân tích địa chấn địa tầng theo quan điểm địa tầng phân tập và các phương pháp địa chất khác, các kết quả đạt được đã cho phép nghiên cứu tỉ mỉ đặc điểm địa chất các thành tạo Pliocen - Đệ tứ vùng biển miền Trung và Đông Nam thềm lục địa Việt Nam.

Trong bài báo này các tác giả trình bày các kết quả nghiên cứu xác định các tập và hệ thống trầm tích, mối quan hệ giữa chu kỳ trầm tích, sự thăng giáng mực nước biển và chuyển động kiến tạo, đặc điểm tướng đá cổ địa lý, lịch sử phát triển địa chất và đặc điểm địa chất công trình trầm tích Pliocen Đệ tứ. Đây là một số kết quả đạt được từ các đề tài KC09.09 và KC09.01/06-10 do các tác giả tiến hành trong các năm 2001-2010 [6, 9].

\section{2. Đặc điểm cấu trúc địa chất}

\subsection{Phân chia địa tầng trầm tích Pliocen - Đệ tứ}

Việc phân chia địa tầng trầm tích Pliocen - Đệ tứ đã được tiến hành trên đất liền đặc biệt là các đồng bằng ven biển trong nhiều năm qua. Tuy nhiên ở thềm lục địa, các nghiên cứu này còn hạn chế, cột địa tầng tổng hợp của các bể trầm tích đều gộp chung trầm tích Pliocen - Đệ tứ là hệ tầng Biển Đông.

Trên cơ sở khảo sát địa chấn phân nông giải cao với mạng lưới tuyến đến độ sâu $200 \mathrm{~m}$ nước, kết hợp với tài liệu địa chấn $2 \mathrm{D}$ và $3 \mathrm{D}$ trong thăm dò dầu khí, việc tiến hành phân tích địa chấn - địa tầng theo nguyên tắc địa tầng phân tập và liên kết với tài liệu địa chất trên đất liền đã cho phép xác lập các đơn vị địa tầng độc lập tuổi Pliocen và Đệ tứ thềm lục địa Việt Nam. Trầm tích Pliocen - Đệ tứ được xác định bởi đáy là các mặt bất chỉnh hợp khu vực. Các phân vị địa tầng chi tiết được phân chia trên cơ sở xác định các hệ thống trầm tích có liên quan đến sự thay đổi mực nước biển và hoạt động kiến tạo là Pliocen dưới $\mathrm{N}_{2}^{1}$; Pliocen trên $\mathrm{N}_{2}{ }^{2}$; Pleistocen dưới $\left(\mathrm{Q}_{1}{ }^{1}\right)$, phần dưới Pleistocen giữa $\left(\mathrm{Q}_{1}{ }^{2 \mathrm{a}}\right)$, phần trên Pleistocen giữa $\left(\mathrm{Q}_{1}{ }^{2 \mathrm{~b}}\right)$, phần dưới Pleistocen trên $\left(\mathrm{Q}_{1}^{3 \mathrm{a}}\right)$, phần trên Pleistocen trên Holocen dưới - giữa $\left(\mathrm{Q}_{1}{ }^{3 \mathrm{~b}}-\mathrm{Q}_{2}{ }^{1-2}\right)$ và Holocen trên $\left(\mathrm{Q}_{2}{ }^{3}\right)[2,4,6,9]$.

Trên hình 1 là kết quả so sánh đường cong thăng giáng mực nước biển vùng nghiên cứu với đường cong thăng giáng mực nước biển khu vực $[3,7]$ nhằm xác định các chu kỳ trầm tích. Trên hình 2 là thí dụ kết quả phân tích địa chấn - địa tầng trầm tích Đệ tứ trên cơ sở địa tầng phân tập của lát cắt địa chấn phân giải cao tuyến MĐC 57-58 vùng biển Phú 


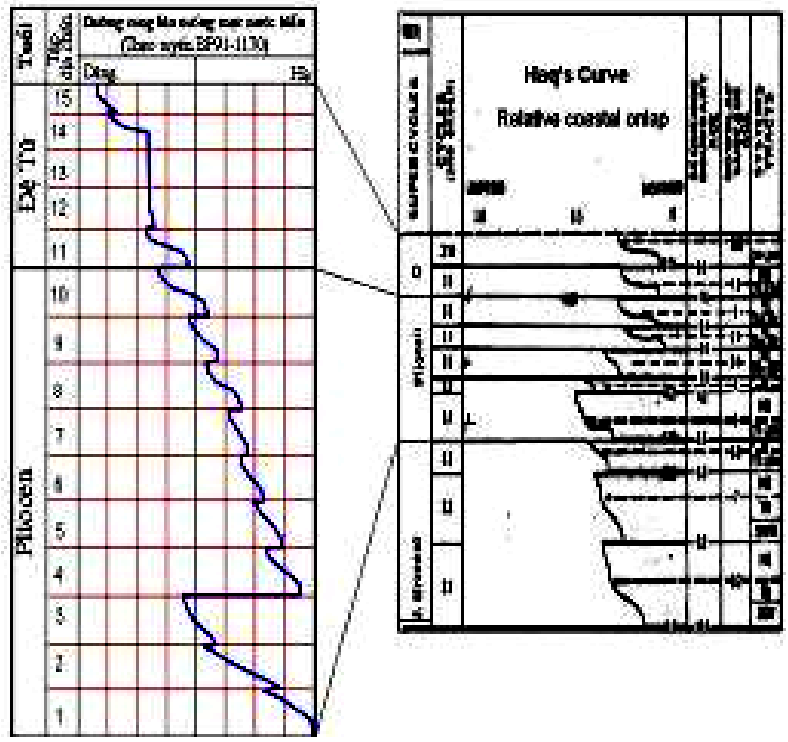

$\leftarrow$ Hình 1. So sánh đường cong thăng giáng mực nước biển vùng nghiên cứu với đường cong của Haq [3]

Yên (thềm lục địa miền Trung). Hình $2 a$ là lát cắt

hìn $2 b$ là lát cắt địa chất tương ứng với các tập địa chấn sau khi phân tích các hệ thống trầm tích; trầm tích trong Pleistocen và Holocen.

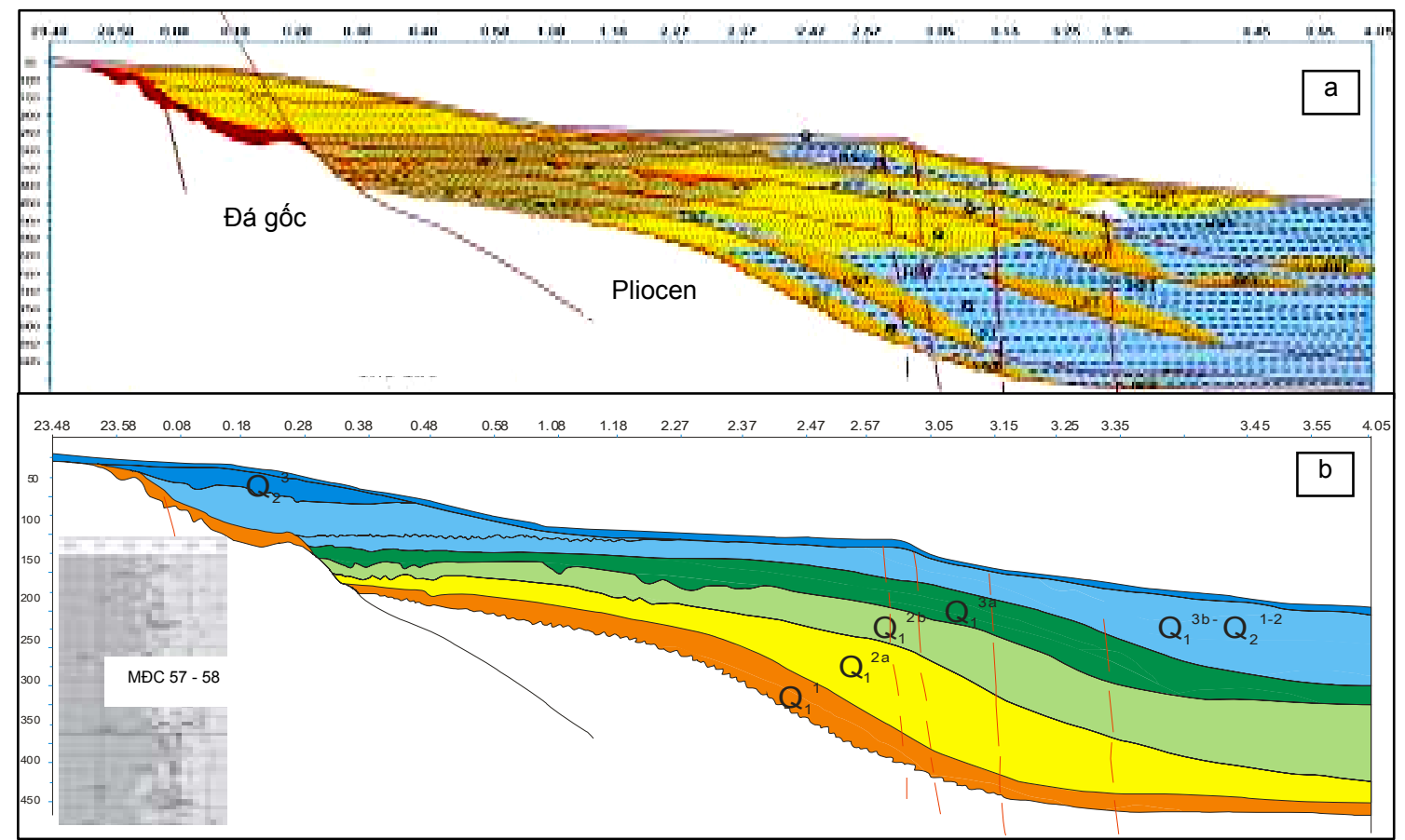

Hình 2. Lát cắt địa chấn (a) và lát cắt địa chất tương ứng (b) tuyến MĐC 57-58

\subsection{Hình thái cấu trúc}

Hình thái cấu trúc Pliocen - Đệ tứ miền Trung và Đông Nam thềm lục địa Việt Nam kế thừa các trầm tích cổ hơn song có nhiều nét khác biệt mang sắc thái riêng. Chiều sâu đáy Pliocen, đáy Đệ tứ và bề dày của chúng thay đổi rất phức tạp ở các vùng khác nhau trên thềm lục địa $[5,7]$. Kết quả nghiên cứu trên cơ sở tài liệu địa chấn phân giải cao, kết hợp với tài liệu địa chấn dầu khí và tài liệu giếng 
khoan cho phép xác định định lượng chiều sâu đáy Pliocen và Đệ tứ, bề dày trầm tích của chúng. Trên cơ sở đó đã xây dựng sơ đồ đẳng sâu, đẳng dày trầm tích Pliocen - Đệ tứ thềm lục địa Việt Nam tỷ lệ $1: 1.000 .000$, tỷ lệ 250.000 và 200.000 cho vùng biển Đông Nam và miền Trung. Căn cứ vào mức độ lắng đọng và bề dày trầm tích, có thể phân chia trầm tích Pliocen - Đệ tứ thềm lục địa Việt Nam thành các miền sụt lún tương ứng với bề dày Pliocen khác nhau $(500 \mathrm{~m}, 500-1000 \mathrm{~m}, 1000$ $2000 \mathrm{~m}$ và $>2000 \mathrm{~m})$.

Trên hình 3 là thí dụ về ranh giới đáy Pliocen và đáy Đệ tứ trên lát cắt địa chấn $2 \mathrm{D}$. Trên hình 4 và hình 5 là các bản đồ đẳng sâu trầm tích Đệ tứ và Pliocen khu vực biển miền Trung và biển Đông Nam (thu nhỏ từ tỷ lệ 1:500.000).

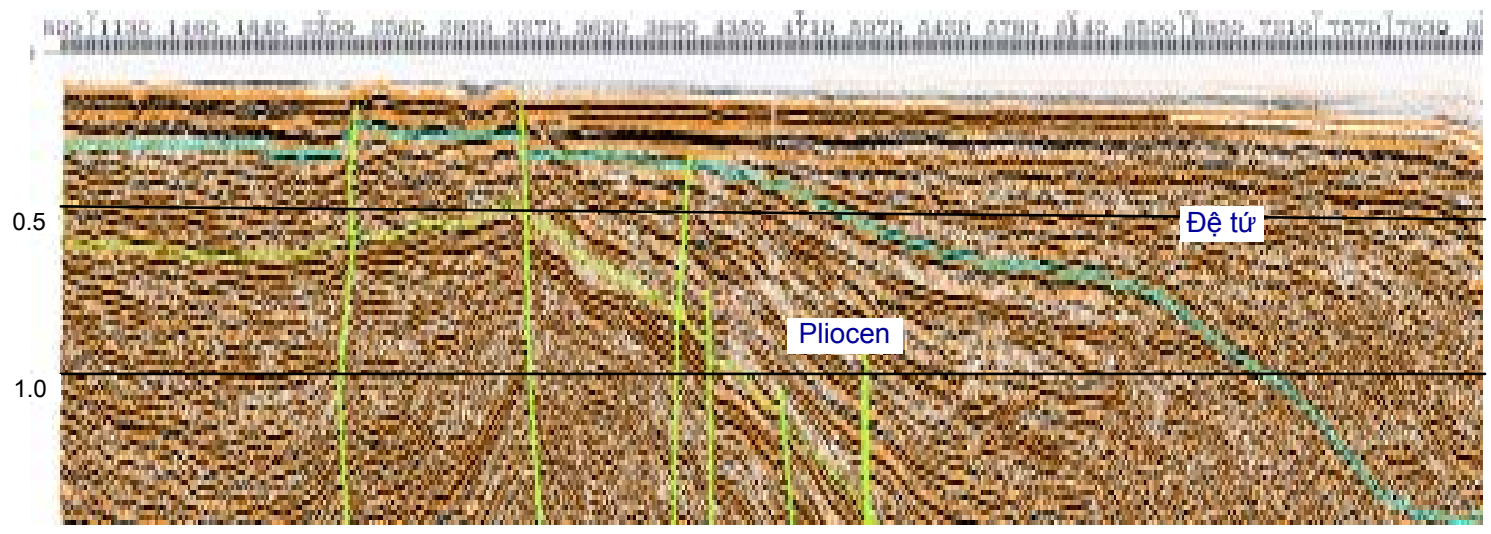

Hình 3. Ranh giới đáy Pliocen và đáy Đệ tứ trên lát cắt địa chấn
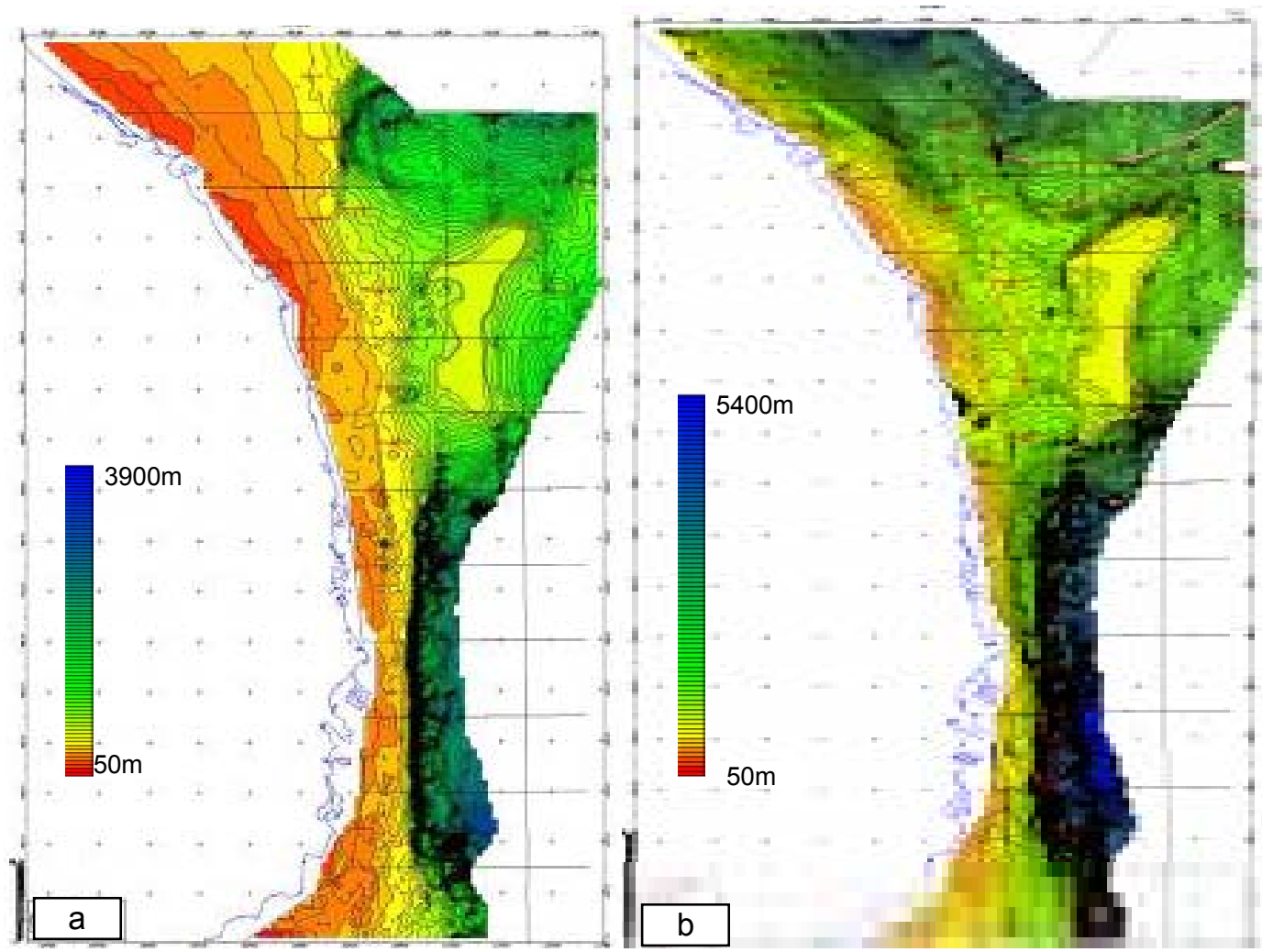

Hình 4. Bản đồ đẳng sâu đáy Đệ tứ (a) và đáy Pliocen (b) thềm lục địa miền Trung 

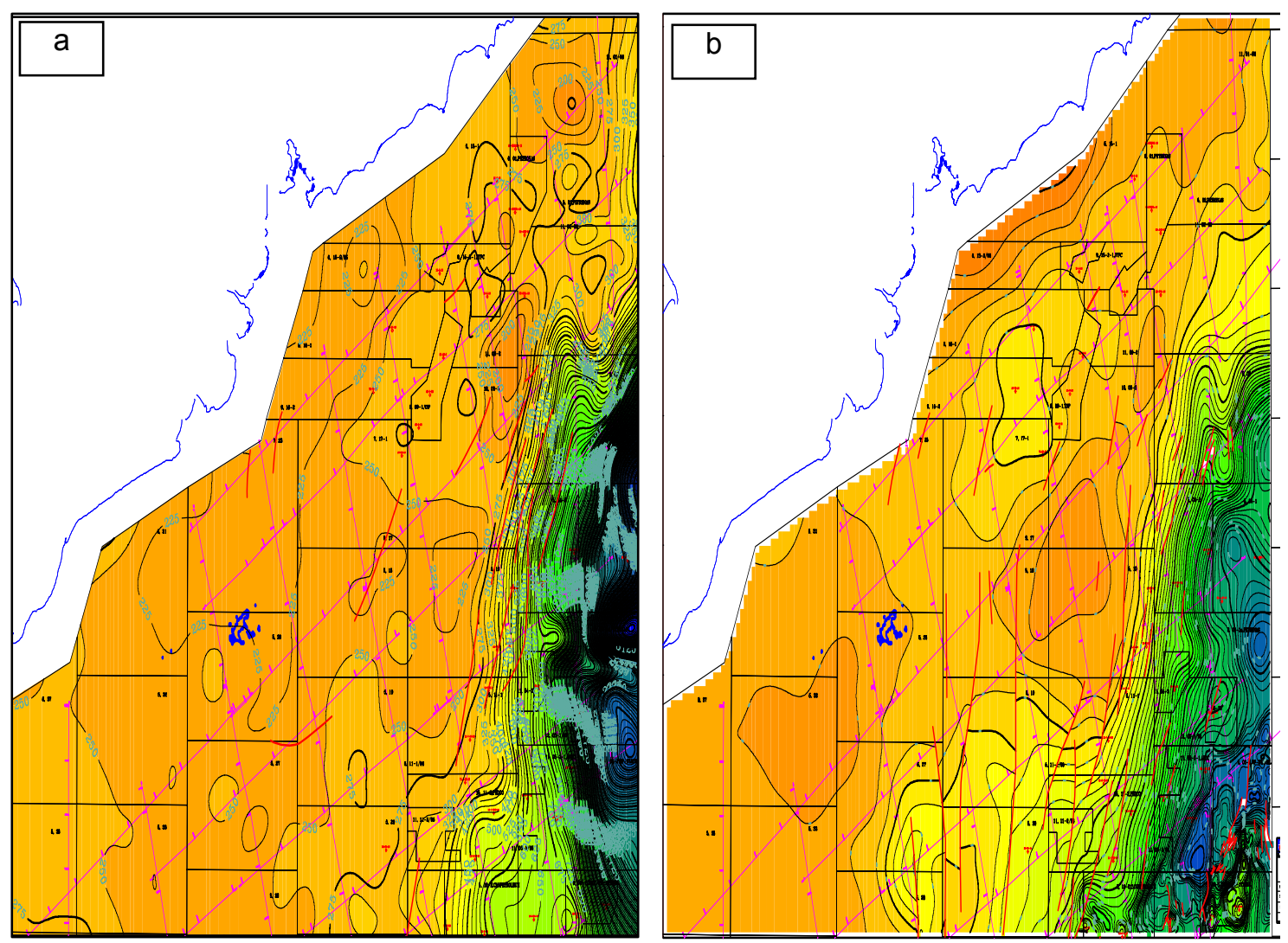

Hình 5. Bản đồ đẳng sâu đáy Đệ tứ (a)và Bản đồ đẳng sâu đáy Pliocen (b) Đông Nam thềm lục địa Việt Nam

\section{3. Đặc điểm tướng đá - cổ địa lý}

Thành phần thạch học, khoáng vật trầm tích, cấp độ hạt của trầm tích Đệ tứ thềm lục địa có đặc điểm khác nhau. Nhìn chung trầm tích lục nguyên chiếm ưu thế, các lớp đá vôi gắn kết yếu, trầm tích núi lửa phân bố không đều. Đới thềm trong giàu aluvi, phát triển vỏ phong hoá, chiều dày nhỏ. Đới thềm giữa nhiều bùn sét và vật liệu núi lửa, chiều dày lớn. Đới thềm ngoài nhiều lớp cát, sạn, các lớp đá vôi và các nêm tăng trưởng vào thời kỳ biển lùi. Ở vịnh Bắc Bộ, loại hạt cỡ bột - sét là chủ yếu, cuối Pleistocen có tầng trầm tích phun trào, môi trường trầm tích châu thổ phát triển từ Pliocen đến Pleistocen muộn; thành phần thạch học chủ yếu loại ít khoáng. Thềm lục địa Trung Bộ đặc trưng bởi trầm tích cát hạt thô và các lớp bùn sinh vật, xuất hiện tầng cát đỏ ven bờ, ở các vũng vịnh phát triển sét, thành phần thạch học phản ánh các loại đá gốc ven bờ. Thềm lục địa vùng Đông Nam có trầm tích hạt mịn chiếm ưu thế; ngoài vật liệu lục nguyên còn có tro bụi núi lửa và phát triển các cồn cát.

Các kết quả nghiên cứu về tướng đá - cổ địa lý đã xác định 8 đường bờ cổ và phân bố các hệ thống lòng sông cổ tương ứng với các thời kỳ băng hà và gian băng, 24 tướng và nhóm tướng trâm tích khác nhau, từ đó cho phép xây dựng các sơ đồ tướng đá cổ địa lý Pliocen - Đệ tứ thềm lục địa Việt Nam [4, 8]. Trên hình 6 là bản đồ tướng đá cổ địa lý khu vực biển miền Trung và vùng biển Đông Nam (thu nhỏ từ tỷ lệ $1: 500.000)$. Các đới đường bờ cổ thềm lục địa bao gồm:

- Đới đường bờ cổ biển lùi trong Pliocen ở độ sâu -3000 đến $-3500 m$ ứng với băng hà Dunai;

- Đới đường bờ cổ của giai đoạn biển lùi trong Pleistocen sớm ở độ sâu $-2000 \mathrm{~m}$ đến $-2500 \mathrm{~m}$ ứng với băng hà Gunzi;

- Đới đường bờ cổ biển lùi trong Pleistocen giữa $\left(\mathrm{Q}_{1}{ }^{2}\right)$ ở độ sâu $-1000 \mathrm{~m}$ đến $-1500 \mathrm{~m}$ ứng với băng hà Mindel; 


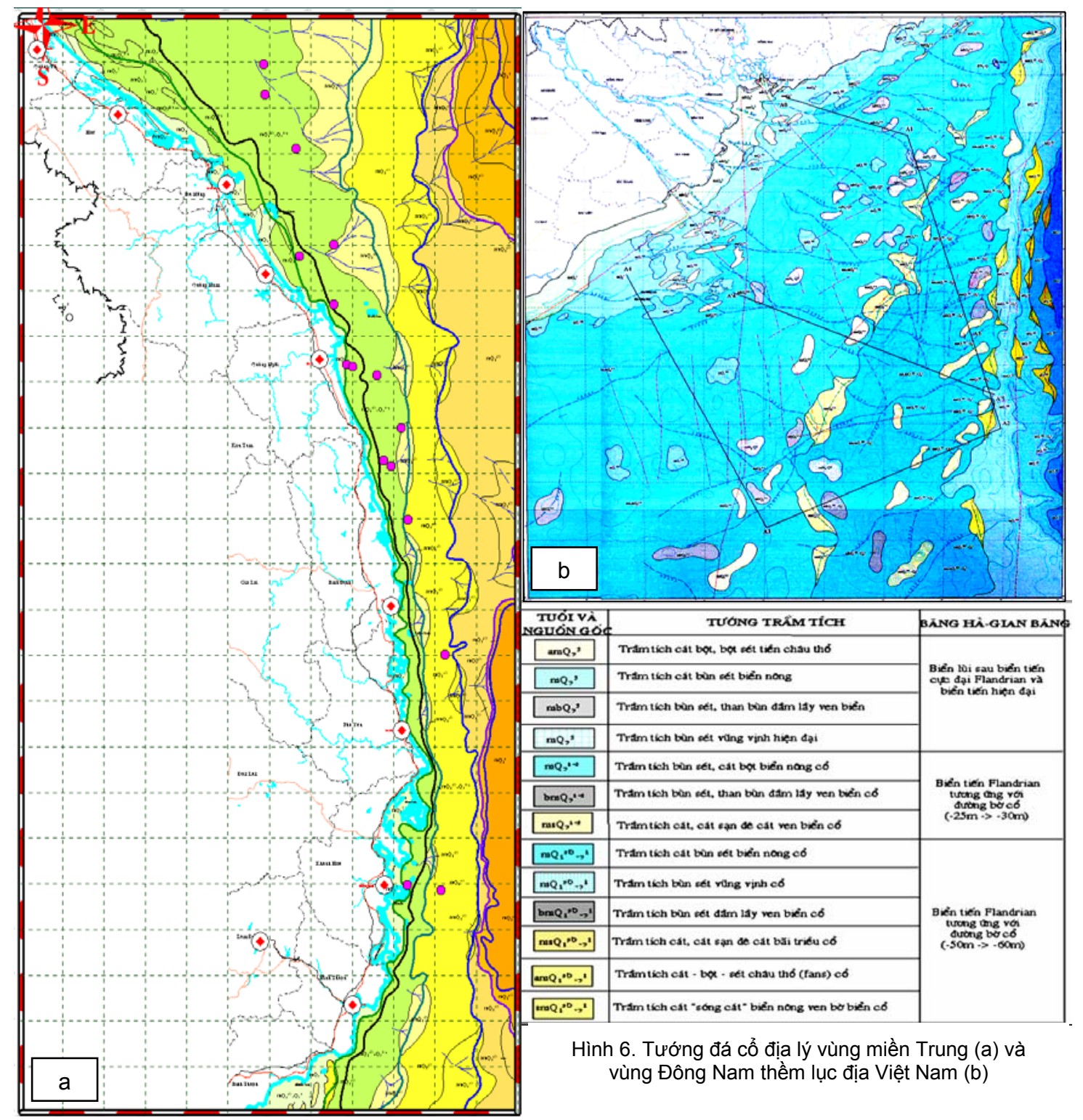

- Đới đường bờ cổ biển lùi cuối Pleistocen giữa $\left(\mathrm{Q}_{1}{ }^{2 \mathrm{~b}}\right)$ ở độ sâu từ $-400 \mathrm{~m}$ đến $-500 \mathrm{~m}$ ứng với băng hà Riss;

- Đới đường bờ cổ biển lùi đầu Pleistocen muộn $\left(\mathrm{Q}_{1}^{3 \mathrm{a}}\right)$ ở độ sâu $-200 \mathrm{~m}$ đến $-300 \mathrm{~m}$ ứng với băng hà Wurm1;

- Đới đường bờ cổ biển lùi cuối Pleistocen muộn $\left(\mathrm{Q}_{1}{ }^{3 \mathrm{~b}}\right)$ ở độ sâu $-100 \mathrm{~m}$ đến $-120 \mathrm{~m}$ ứng với băng hà cuối cùng Wurm2;

- Đới đường bờ cổ biển tiến Flandrian Pleistocen muộn - Holocen sớm $\left(\mathrm{Q}_{1}{ }^{3}-\mathrm{Q}_{2}{ }^{1}\right)$ ở độ sâu từ -50 đến $-60 m$;

- Đới đường bờ biển tiến Flandrian Holocen sớm - giữa $\left(\mathrm{Q}_{2}{ }^{1}-\mathrm{Q}_{2}{ }^{2}\right)$ ở độ sâu từ -25 đến $-30 \mathrm{~m}$.

Giai đoạn Holocen muộn từ 4000 năm $\left(\mathrm{Q}_{2}{ }^{3}\right)$ có pha biển lùi và pha biển tiến hiện đại từ 1000 năm trở lại đây, bờ biển Việt Nam liên tục bị biến động theo cả hai hướng bồi tụ và xói lở. Đây là bức tranh về lịch sử hình thành và tiến hoá trầm tích, khí hậu, cảnh quan địa lý tự nhiên trong mối quan hệ giữa sự thay đổi mực nước biển và chuyển động kiến tạo, là cơ sở để lựa chọn các phương án chi tiết khi xây dựng các công trình ngoài khơi và ven bờ.

Trầm tích Pliocen - Đệ tứ phần đất liền và biển có mối quan hệ ngược chiều do sự dao động mực 
nước biển đại dương. Trong cùng một tuổi, mực nước cạn nhất (băng hà) tạo nên đới bờ sâu và xa bờ hiện đại nhất, đồng thời mực nước cao nhất (gian băng) tạo nên đường bờ (thềm biển) cao và cũng xa đường bờ hiện đại nhất. Đới bờ hiện nay là sự hội tụ các chu kỳ chuyển động của biển lùi biển tiến theo quy luật giảm dần đều và trở lại trạng thái ổn định tương đối. Càng ra sâu bề dày trầm tích Đệ tứ càng mỏng do sự sụt lún kiến tạo và sự dịch chuyển dần đường bờ cổ vào phía đất liền đồng thời với hiện tượng khuyết dần các chu kỳ trầm tích trẻ.

\section{3 . Đặc điểm kiến tạo địa động lực}

\section{1. Đặc điểm kiến tạo hiện đại}

Các kết quả nghiên cứu cho thấy chế độ kiến tạo trong giai đoạn Pliocen - Đệ tứ thềm lục địa Việt Nam có những đặc điểm sau:

- Quá trình sụt lún phân dị chiếm ưu thế; tất cả các kiến trúc Kainozoi sớm (các bể trầm tích Đệ tam và các đới nâng đều tham gia vào quá trình này với mức độ khác nhau tùy thuộc sự chuyển động phân dị các khối đứt gãy của móng thềm lục địa. Bình đồ sụt lún thay đổi theo thời gian và tạo nên các bất chỉnh hợp kiến trúc trong các bể trầm tích Pliocen - Đệ tứ.

- Các bể trầm tích Pliocen - Đệ tứ vịnh Bắc Bộ, Sông Hồng, Phú Khánh, Cửu Long, Nam Côn Sơn và Malay - Thổ Chu có bản sắc phát triển riêng của mình. Đặc điểm này thể hiện ở tốc độ sụt lún, môi trường trầm tích, tính kế thừa bình đồ kiến trúc cổ và tổ hợp các thành tạo trầm tích, trầm tích - phun trào khác nhau. Đặc biệt là sự xuất hiện tướng trầm tích dòng chảy rối (turbidit) cùng với sự hình thành các nêm lấn từ đầu Pliocen và tiếp tục phát triển trong suốt Pliocen - Đệ tứ ở rìa phía đông các bể Phú Khánh và Nam Côn Sơn.

- Hệ thống đứt gãy kiến tạo tiếp tục hoạt động và đóng vai trò quan trọng trong việc tạo dựng bình đồ kiến trúc thềm lục địa Việt Nam. Trong diện phân bố các thành tạo Pliocen - Đệ tứ có xuất hiện các hệ thống đứt gãy hoạt động trong Pliocen - Đệ tứ. Chúng có phương chủ yếu là á kinh tuyến, đôi nơi có phương á vỹ tuyến và ĐB-TN.

- Hoạt tính kiến tạo Kainozoi muộn không có dấu hiệu suy giảm, ghi nhận được xu thế tăng cường hoạt tính kiến tạo - địa động lực tập trung dọc theo các hệ thống đứt gãy sâu, là ranh giới phân chia các kiến trúc kiến tạo chủ yếu, nổi bật là đới đứt gãy phương kinh tuyến $109^{\circ}$ và đới đứt gãy Sông Hồng.

Sơ đồ cấu trúc Pliocen - Đệ tứ thềm lục địa miền Trung được thể hiện trên hình 7.

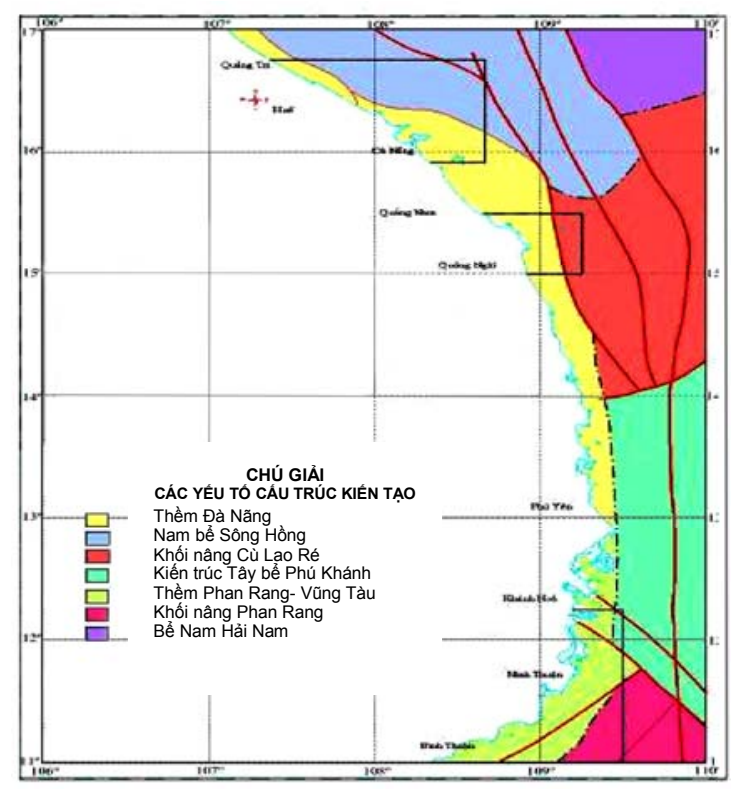

Hình 7. Sơ đồ cấu trúc Pliocen - Đệ tứ thềm lục địa miền Trung

\section{2. Đặc điểm địa động lụcc}

Các hoạt động nội động lực hiện đại thềm lục địa Việt Nam biểu hiện rất đa dạng. Trường dòng nhiệt khu vực phản ánh các bất đồng nhất theo chiều sâu của kiến trúc thềm lục địa và kiến trúc trũng nước sâu đại dương Biển Đông kế cận và các trục sụt lún trong nội bộ thềm lục địa. Các hoạt động núi lửa hiện đại phản ánh mức độ sâu của các quá trình magma hiện đại và cùng với các biểu hiện của hoạt động động đất khắc họa thêm các đới tập trung hoạt tính kiến tạo - địa động lực hiện đại là: đới Sông Hồng, đới kinh tuyến Hải Nam - eo biển Sunda, đới rìa trong Thuận Hải - Minh Hải và đới Hòn Hải - Cảnh Dương $[1,8]$.

Các chế độ địa động lực hiện đại (nội động lực và ngoại động lực) đã làm nảy sinh các tai biến tiềm tàng hiểm họa là động đất, xói lở bờ biển $[1$, 10]. Kết quả nghiên cứu cho thấy đới ven biển và đới bờ là nơi biểu hiện tập trung các tai biến động đất, xói lở bờ biển và nguy cơ tàn phá của sóng thần do các trận động đất mạnh của khu vực gây 
ra; đới động lực của hệ đứt gãy á kinh tuyến Hải Nam - eo biển Sunda là nơi tập trung các biểu hiện hoạt động động đất và núi lửa nguy hiểm nhất. Trên hình 8, 9 là bản đồ kiến tạo, địa động lực Pliocen - Đệ tứ thềm lục địa miền Trung và vùng Đông Nam (thu nhỏ từ tỷ lệ 1:500.000).

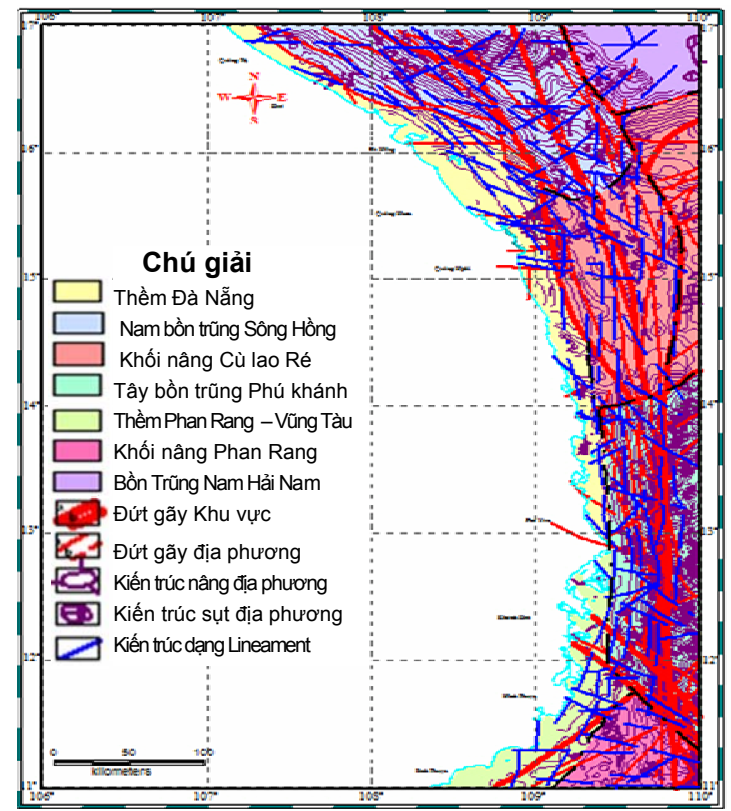

Hình 8. Bản đồ kiến tạo địa động lực Pliocen - Đệ tứ thềm lục địa miền Trung

\section{4. Đặc điểm địa chất công trình}

Đặc điểm địa chất công trình được nghiên cứu trên quy mô toàn thềm lục đia Việt Nam, đã đưa ra một quy trình nghiên cứu toàn điện và có hệ thống phục vụ đánh giá điều kiện xây dựng công trình biển $[6,9,11]$. Phân tích tướng trầm tích từ tài liệu địa chấn phân giải cao được minh họa trên hình 10 . Bản đồ địa chất công trình và phân vùng địa chất công trình vùng Đông Nam thềm lục địa Việt Nam được thể hiện trên hình 11. Các thể địa chất biểu thị trên bản đồ được nêu trên bảng 1 . Từ các kết quả đạt được có thể nêu một số tóm tắt như sau:

- Nghiên cứu tính chất cơ lý của trầm tích theo phức hệ địa tầng nguồn gốc cho phép làm sáng tỏ mối liên hệ về nguồn gốc, tuổi địa chất và mức độ tạo đá trong sự hình thành tính chất của chúng. Quá trình phong hóa laterit trong các giai đoạn biển lùi làm phức tạp hóa quá trình phát triển độ bền của các trầm tích theo mức độ nén chặt trọng lực.
- Xác lập và làm sáng tỏ quy luật biến đổi không gian điều kiện địa chất công trình thềm lục địa Việt Nam là vừa biến đổi theo các đới sâu nước, vừa theo các vùng trên bình đồ thềm lục địa là Vịnh Bắc Bộ, Trung Bộ, Đông Nam Bộ và Tây Nam Bộ.

- Các kết quả nghiên cứu đã xác định sự có mặt của nước lợ ở sâu tại vùng mỏ Bạch Hổ, củng cố cho nhận định nước dưới đất nhạt phân bố sâu tại đồng bằng Cửu Long là nước có nguồn gốc chôn vùi. Điều này cho thấy trữ lượng nguồn nước nhạt này là có hạn và lượng nước có thể khai thác bị hạn chế.

Bảng 1. Các thể địa chất biểu thị trên bản đồ địa chất công trình

\begin{tabular}{|c|c|c|c|c|}
\hline Lớp & Nhóm & $\begin{array}{l}\text { Phụ } \\
\text { nhóm }\end{array}$ & $\begin{array}{c}\text { Phức hệ địa tầng } \\
\text { nguồn gốc }\end{array}$ & Đất đá \\
\hline \multirow{10}{*}{ 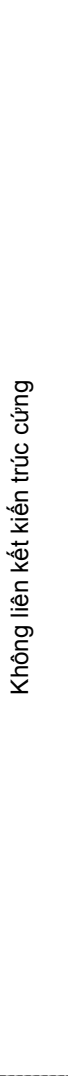 } & \multirow{10}{*}{ 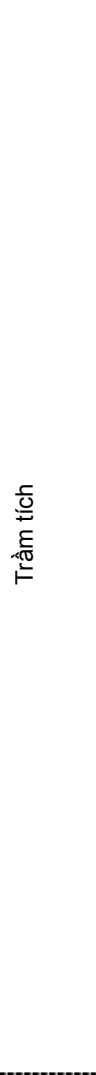 } & \multirow{10}{*}{ 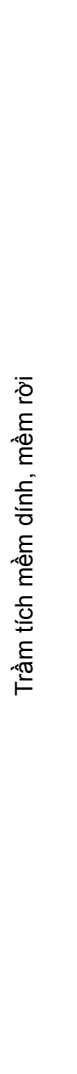 } & $(\mathrm{am}, \mathrm{bm}) \mathrm{Q}_{2}{ }^{3}$ & $\begin{array}{l}\text { Sét, sét pha, cát pha } \\
\text { mềm yếu, cát, bùn } \\
\text { sét, bùn sét pha, bùn } \\
\text { cát pha }\end{array}$ \\
\hline & & & $\mathrm{mQ}_{2}{ }^{3}$ & $\begin{array}{l}\text { Sét, sét pha dẻo } \\
\text { mềm, } \\
\text { dẻo chảy, cát pha } \\
\text { dẻo, cát }\end{array}$ \\
\hline & & & $\mathrm{msQ}_{2}^{1-2}$ & $\begin{array}{l}\text { Cát sỏi, } \\
\text { cát hạt trung }\end{array}$ \\
\hline & & & $m\left(Q_{1}{ }^{3 b}-Q_{2}{ }^{1-2}\right)$ & $\begin{array}{l}\text { Sét, sét pha dẻo } \\
\text { mềm, dẻo cứng đến } \\
\text { nửa cứng, cát pha, } \\
\text { cát hạt nhỏ, hạt trung } \\
\text { chặt vừa }\end{array}$ \\
\hline & & & $a m Q_{1}{ }^{3 b}$ & $\begin{array}{l}\text { Cát các loại, cát pha, } \\
\text { sét pha }\end{array}$ \\
\hline & & & $\mathrm{mQ}_{1}{ }^{3 a}$ & $\begin{array}{l}\text { Sét, sét pha dẻo } \\
\text { cứng, } \\
\text { nửa cứng, cát pha } \\
\text { dẻo }\end{array}$ \\
\hline & & & $\mathrm{amQ}_{1}{ }^{3 \mathrm{a}}$ & Cát, cát sỏi, cát pha \\
\hline & & & $(\mathrm{m}, \mathrm{am}) \mathrm{Q}_{1}{ }^{2 \mathrm{~b}}$ & $\begin{array}{l}\text { Sét, sét pha dẻo } \\
\text { cứng đến cứng, cát } \\
\text { chặt đến rất chặt }\end{array}$ \\
\hline & & & $(\mathrm{m}, \mathrm{am}) \mathrm{Q}_{1}^{2 \mathrm{a}}$ & $\begin{array}{l}\text { Sét, sét pha chứa } \\
\text { nhiều cacbonat }\end{array}$ \\
\hline & & & $\mathrm{mQ}_{1}{ }^{1}$ & $\begin{array}{l}\text { Sét, sét pha nửa } \\
\text { cứng đến cứng }\end{array}$ \\
\hline 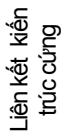 & $\begin{array}{l}\frac{\pi}{E} \\
\sum^{\pi} \\
\Sigma\end{array}$ & 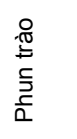 & $\beta\left(N_{2}-Q\right)$ & Đá bazan \\
\hline
\end{tabular}




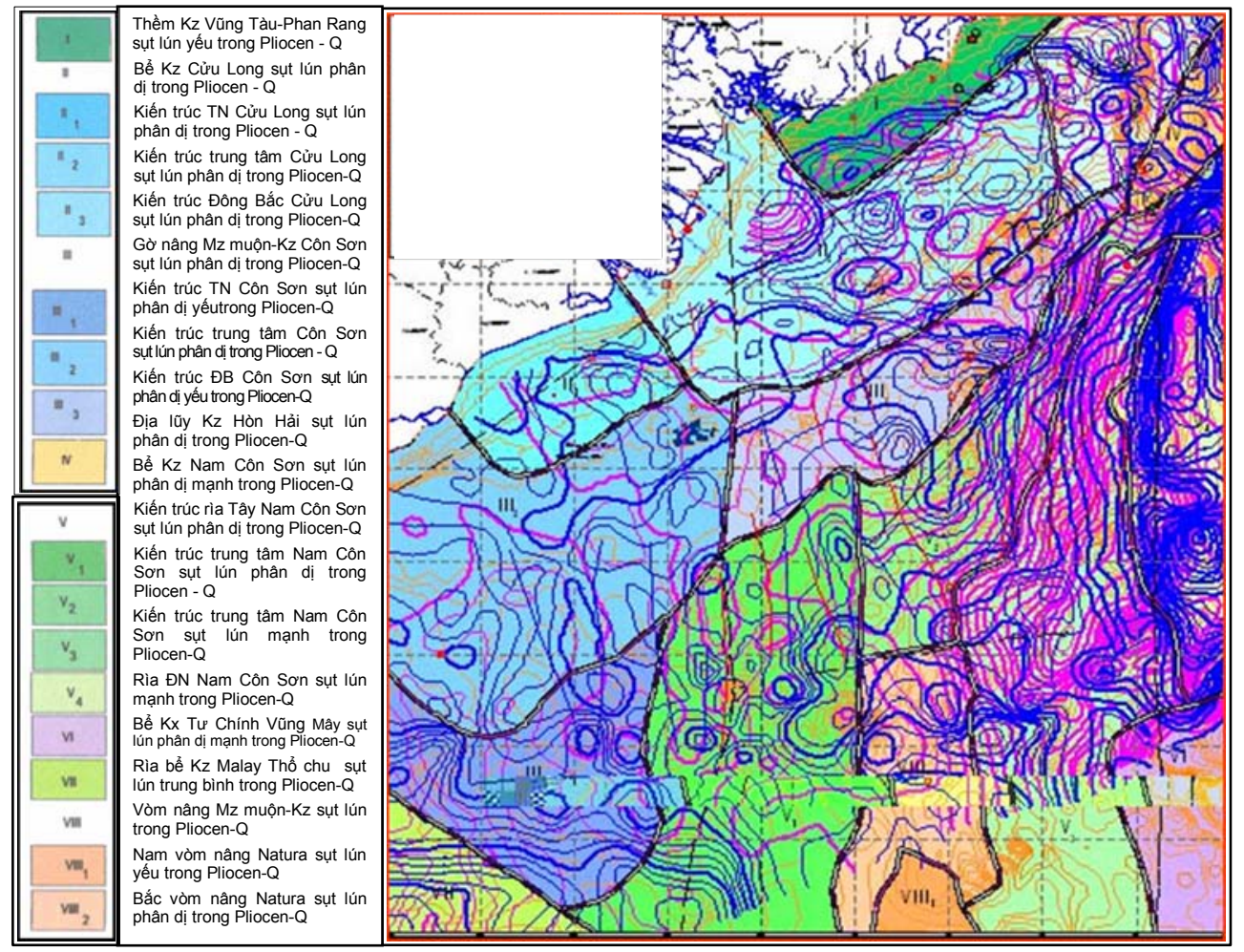

Hình 9. Bản đồ kiến tạo, địa động lực Pliocen - Đệ tứ thềm lục địa Đông Nam

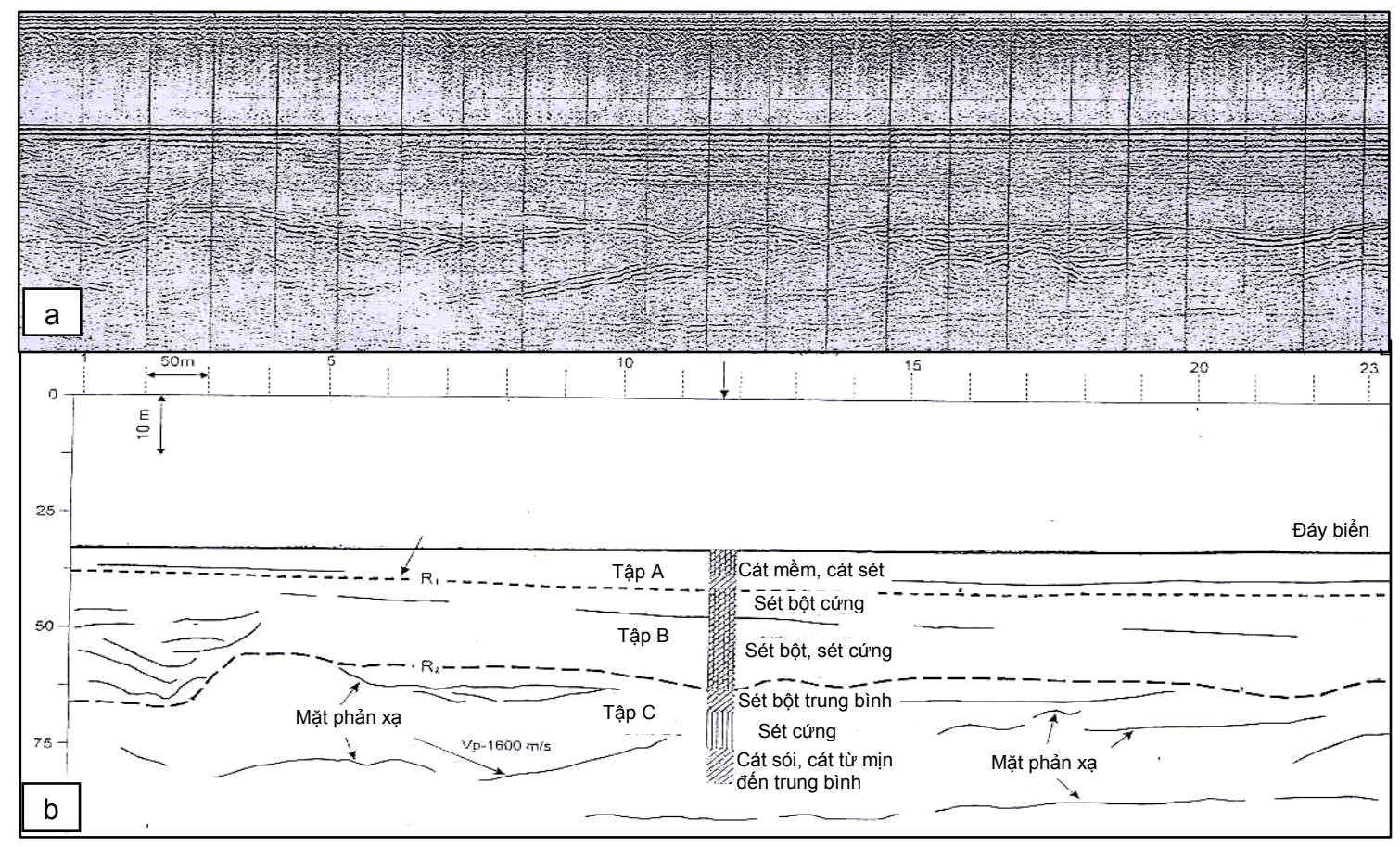

Hình 10. Phân tích tướng trầm tích từ tài liệu địa chấn phân giải cao 

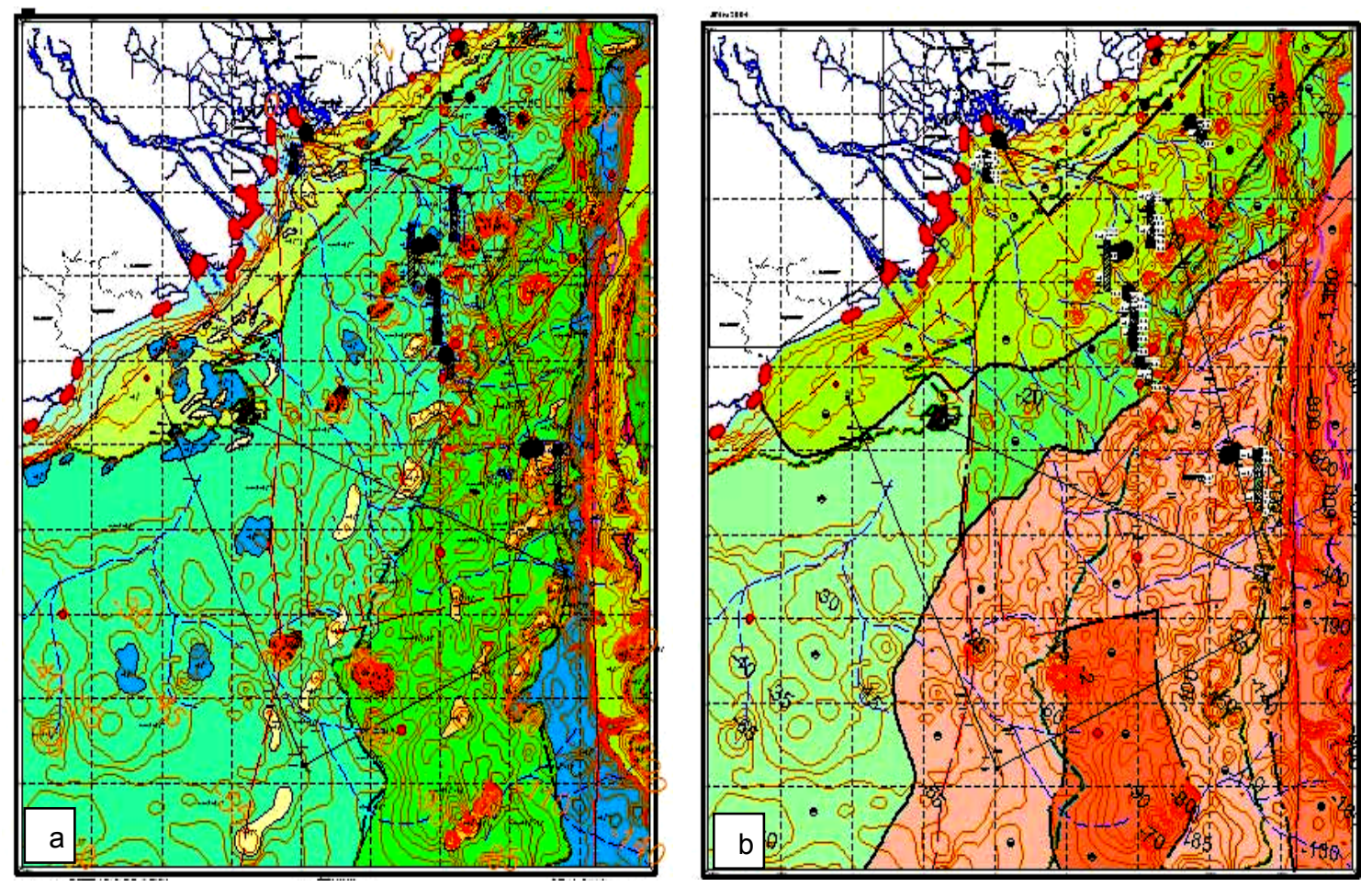

Hình 11. Bản đồ địa chất công trình (a) và phân vùng địa chất công trình (b) vùng Đông Nam thềm lục địa Việt Nam (thu nhỏ từ tỷ lệ 1:500.000)

\section{Kết luận}

- Phân tích địa chấn - địa tầng trên cơ sở địa tầng phân tập và liên kết với tài liệu địa chất cho phép xác định hình thái cấu trúc, chiều sâu và bề dày trầm tích Pliocen và Đệ tứ. Các phân vị địa tầng được phân chia gồm $\mathrm{N}_{2}{ }_{2} ; \mathrm{N}_{2}{ }^{2} ; \mathrm{Q}_{1}{ }^{1}, \mathrm{Q}_{1}{ }^{2 \mathrm{a}}, \mathrm{Q}_{1}{ }^{2 \mathrm{~b}}$, $\mathrm{Q}_{1}{ }^{3 \mathrm{a}}, \mathrm{Q}_{1}{ }^{3 \mathrm{~b}}-\mathrm{Q}_{2}{ }^{1-2}$ và $\mathrm{Q}_{2}{ }^{3}$.

- Các kết quả nghiên cứu đã xác định hệ thống các đường bờ cổ tương ứng với các thời kỳ băng hà và gian băng, phân chia các tướng và nhóm tướng trầm tích, từ đó xây dựng các sơ đồ tướng đá cổ địa lý Pliocen - Đệ tứ thềm lục địa Việt Nam.

- Các bể trầm tích Pliocen - Đệ tứ có tốc độ sụt lún, môi trường trầm tích, tính kế thừa bình đồ kiến trúc cổ và tổ hợp các thành tạo trầm tích khác nhau. Các hệ thống đứt gãy trong có phương chủ yếu là á kinh tuyến. Hoạt tính kiến tạo - địa động lực tập trung dọc theo các hệ thống đứt gãy sâu. Chế độ địa động lực hiện đại làm nảy sinh các tai biến tiềm tàng, đới ven biển và đới bờ tập trung các tai biến động đất, xói lở bờ biển.
- Lần đầu tiên đặc điểm địa chất công trình được nghiên cứu trên thềm lục địa Việt Nam. Nghiên cứu tính chất cơ lý của trầm tích cho phép làm sáng tỏ mối liên hệ về nguồn gốc, tuổi địa chất và mức độ thành đá. Xác lập và làm sáng tỏ quy luật biến đổi không gian điều kiện địa chất công trình thềm lục địa theo các đới sâu nước và theo các vùng.

\section{TÀI LIẸU DÃNN}

[1] Lê Duy Bách, Ngô Gia Thắng, 2008: Các kiểu bồn trũng Kainozoi khu vực biển rìa đông Việt Nam. Tuyển tập Hội nghị khoa học Địa chất biển toàn quốc lần thứ nhất, tr. 114-124.

[2] Nguyễn Biểu, Mai Thanh Tân, Trần Nghi, Nguyễn Thị Hồng Liễu, Nguyến Quốc Hung, 2008: Địa tầng phân tập phân giải cao trầm tích PliocenĐệ tứ biền Nam Trung Bộ, Tuyển tập Hội nghị khoa học Địa chất Biển toàn quốc lần thứ nhất, tr.199-209.

[3] Haq, B.U., Hardenbol, J., Vail, P.R., 1987: Chronology of fluctuating sea - levels since the Triassic. Science, v. 235, p. 1156-1167. 
[4] Trần Nghi, 2001: Đặc điểm tướng đá - cổ địa lý trong Pliocen Đệ tứ thềm lục địa Việt Nam, Tạp chí các Khoa học về Trái Đất, T. 23(2), Hà Nội, tr. 105-116.

[5] Mai Thanh Tân, 2004: Application of Geophysical methods to study the Pliocene Quaternary sediments in the Continental Shelf of Vietnam, Advances in Natural Sciences, vol.5, N0.2, pp. 201-208.

[6] Mai Thanh Tân (chủ biên), 2005: Nghiên cứu đặc điểm địa chất - địa chất công trình vùng Đông Nam thềm lục địa Việt Nam phục vụ chiến lược phát triển kinh tế và xây dựng cồng trình biển. Đề tài nghiên cứu khoa học cấp Nhà nước KC09.09.

[7] Mai Thanh Tân, Lê Văn Dung, Lê Đình Thắng, 2008: Hình thái cấu trúc địa chất Pliocen Đệ Tứ thềm lục địa Việt Nam. Tuyển tập Hội nghị khoa học Địa chất biển toàn quốc lần thứ nhất, tr. 188-198.
[8] Mai Thanh Tân (chủ biên), 2009: Biển Đông, tập III, Địa chất và Địa vật lý Biển. Nhà xuất bản Khoa học Tự nhiên và Công nghệ. 517 tr.

[9] Mai Thanh Tân (chủ biên), 2010: Nghiên cứu đặc điểm địa chất - địa chất công trình vùng thềm lục địa miền Trung Việt Nam phục vụ cho việc xây dựng công trình biển và định hướng phát triển kinh tế biển. Đề tài nghiên cứu khoa học cấp Nhà nước KC09.09.01/06-10.

[10] Cao Đình Triều, 2010: Tai biến động đất ở Việt Nam. Nxb. Khoa học và Kỹ thuật. 303 tr.

[11] Pham Van Ty, Mai Thanh Tan, Nguyen Viet Tinh, Pham Thi Viet Nga, 2005: The geological Engineering zoning in South - Eastern Continental Shelf of Vietnam, Proceedings of the international Workshop "Integrated Geoengineering for a Sustainnable Infrastrucure Development", Hanoi National University Publishing House, pp. 162-166.

\section{SUMMARY}

\section{Characteristics of Pliocene - Quaternary geology and Geoengineering in the}

Center and Southeast parts of Continental Shelf of Vietnam

Vietnam has a large continental shelf with complicated geological characteristics. The study of the PlioceneQuaternary sediments is very important for understanding the shallow geological characteristics, potential of mineral resources, as well as the evaluation of offshore construction sites conditions. By the combination of HRS, 2-D, 3-D seismic and other geological methods, the detailed investigating results of the Pliocene - Quaternary formations in the Center and Southeast parts of continental shelf of Vietnam have been obtained.

In this paper, the authors present the research results of establishing the structural maps, determining the sedimentary system tracts and sequences, the relationship between sedimentary cycles, sea level change and tectonic movement, facial-paleogeographic characteristics, geological development history and characteristics of engineering geology Pliocene - Quaternary. 